\title{
Overexpression of Tissue Inhibitor of Metalloproteinases-3 in Intestinal and Cutaneous Lesions of Graft-versus-Host Disease
}

\author{
M. T. Salmela, M.D., M. L. Karjalainen-Lindsberg, M.D., Ph.D., L. Jeskanen, M.D., \\ U. Saarialho-Kere, M.D., Ph.D. \\ Departments of Dermatology (MTS, LJ, US-K) and Pathology (MLK-L), Helsinki University Central \\ Hospital, Helsinki, Finland
}

\begin{abstract}
Matrix metalloproteinases (MMPs) have been implicated in the pathobiology of various T-cell-mediated inflammatory disorders of the intestine and skin. Their synthetic inhibitor has been shown to prevent lethal acute graft-versus-host disease in animal models. We intended to determine the expression of MMPs 1, 3, 7, 9, 10, 12, and 19 and tissue inhibitors of metalloproteinases (TIMPs) 1 and 3 in intestinal and cutaneous lesions of patients suffering from graft-versus-host disease after bone marrow transplantation. In situ hybridizations for MMPs $1,3,7,10$, and 12 as well as TIMPs 1 and 3 were performed using ${ }^{35}$ S-labeled cRNA probes on intestinal $(n=13)$ and cutaneous specimens $(n=9)$ from patients with graft-versus-host disease. Immunohistochemical stainings were carried out to localize MMP-9, MMP-19, TIMP-3, and TGF- $\beta 1$ proteins, and TUNEL staining, to detect apoptotic cells. TIMP-3 mRNA and protein were detected in cutaneous lesions in areas with vacuolar degeneration of the basal epidermal layer in all skin samples, and they colocalized with apoptotic keratinocytes and partly with staining for TGF- $\beta$. None of the MMPs examined were overexpressed in skin lesions. Signals for MMP-1 and MMP-3 mRNA was found in $10 / 13$ and $5 / 13$ intestinal biopsies, respectively. In the gut, MMP-19-positive epithelial cells, particularly in the crypts, were found in $10 / 13$ samples. Expression of MMPs 7, 9, 10, and 12 was absent or very low. TIMPs 1 and 3 were expressed by stromal
\end{abstract}

Copyright (C) 2003 by The United States and Canadian Academy of Pathology, Inc.

VOL. 16, NO. 2, P. 108, 2003 Printed in the U.S.A

Date of acceptance: November 11, 2002.

Supported by The Academy of Finland, the Sigrid Juselius Foundation, Finska Läkaresällskapet, Helsinki University Central Hospital Research Funds, Biomedicum Foundation, Emil Aaltonen Foundation, and Research and Science Foundation of Farmos.

Address reprint requests to: U. Saarialho-Kere, M.D., Ph.D., Department of Dermatology, Helsinki University Central Hospital, Meilahdentie 2, 00250 Helsinki, Finland; fax: +358-9-4718 6561; e-mail: ulpu.saarialho-kere@helsinki.fi.

DOI: $10.1097 / 01 . M P .0000051681 .43441 .82$ cells in $12 / 13$ and $10 / 13$ gut samples, respectively. Whereas TIMP-1 was expressed particularly by subepithelial cells where epithelium had shed away, TIMP-3 was detected in deeper areas. We conclude that MMPs are differentially regulated in the skin and gut lesions of graft-versus-host disease. In agreement with previous data on cancer cells, TIMP-3, induced by TGF- $\beta 1$, may contribute to the apoptosis of keratinocytes in cutaneous graftversus-host disease lesions, leading to typical histopathological changes. We also conclude that MMPs play a less important role as effector molecules in intestinal graft-versus-host disease than in celiac or inflammatory bowel disease.

KEY WORDS: Apoptosis, Collagenase, Matrilysin, MMP-19, TIMP.

Mod Pathol 2003;16(2):108-114

Graft-versus-host disease is the major cause of morbidity and mortality after bone marrow transplantation and is sometimes, though more rarely, threatening patients after liver transplantation (1, 2). In graft-versus-host disease, immunocompetent donor lymphocytes from transplanted bone marrow or liver recognize and react against recipient's tissues, leading to cutaneous and intestinal lesions. Commonly, the first manifestation of acute graftversus-host disease is pruritic maculopapular skin rash characterized by typical histopathological findings such as vacuolar degeneration of the basal cell layer, basal cell necrosis, Langerhans cell depletion, intercellular edema, and acantholysis $(1,2)$. Intestinal manifestations of acute graft-versus-host disease include diarrhea, abdominal cramping, intestinal bleeding, and vomiting. Endoscopic findings range from normal to extensive edema, mucosal sloughing and bleeding, and histology reveals, for example, crypt-cell necrosis $(1,2)$.

Matrix metalloproteinases (MMPs) are a family of $\mathrm{Ca}^{2+}$-dependent zinc-ion containing endopepti- 
dases. Since the early sixties, 21 human members of this enzyme family have been cloned. According to their structure and substrate specificity, MMPs can be grouped into collagenases (MMP-1, -8, and 13), gelatinases (MMP-2 and -9), stromelysins (MMP-3, $-10,-11$, and -12), membrane-type metalloproteinases (MMP-14, -15, -16, -17, and -24), matrilysins (MMP-7 and -26), and other MMPs (MMP-19, -20, $-23,-25$, and $-28 ; 3,4)$. MMPs are regulated mainly at the transcriptional level, and their enzymatic activity can be inhibited by tissue inhibitors of metalloproteinases (TIMP), a protein group that currently comprises four members (TIMP-1, $-2,-3$, and -4). TIMP-1 inhibits the activity of most MMPs except MMP-2 and MT1-MMP $(5,6)$. TIMP-3 inhibits the activity of MMPs $-1,-2,-3,-9$, and -13 (7). In addition, it inhibits the endopeptidase TACE (ADAM-17) (8), which can shed TNFR1 and TNF- $\alpha$ from the cell surface. MMPs play an important role in several physiological and pathological processes such as fetal development; wound healing; inflammatory bowel disease; rheumatoid arthritis; and cancer growth, invasion, and metastasis (3).

Matrix metalloproteinases and TIMPs have previously been implicated in the pathomechanism of several inflammatory disorders of the skin and intestine, such as celiac disease, ulcerative colitis, and Crohn's disease $(9,10)$, as well as granulomatous skin disorders, lichen planus, and scleroderma (11-14). Several studies have shown the expression of various MMPs, particularly MMPs $-1,-3,-12$ and -14 , in intestinal ulcers of patients with inflammatory bowel disease (9, $10,15,16)$. Functional evidence for the critical role of MMPs, particularly that of MMP-3, in mucosal injury comes from studies using a fetal model for T-cellmediated injury of the gut $(17,18)$. In this model, the synthetic MMP inhibitor prevents mucosal injury after $\mathrm{T}$ cell activation.

The synthetic MMP inhibitor (KB-R7785), with activity against MMPs- $1,-3$, and -9 , prevents acute graft-versus-host disease but preserves graft-versusleukemia effect in mice undergoing allogeneic bone marrow transplantation $(19,20)$. TNF- $\alpha$ and FasL, both released and activated by MMPs $(3,21)$, are implicated in the pathogenesis of acute graftversus-host disease (22). In addition to the effects of MMPs on the activation of cytokines or on the shedding of their receptors (23), they might function as end-stage effector molecules in intestinal and cutaneous lesions also in graft-versus-host disease. Therefore, we wanted to investigate whether MMPs 1, 3, 7, 9, 10, 12, and 19 and TIMPs 1 and 3 are expressed in graft-versus-host disease-related lesions of the skin and intestine. Our results indicate that TIMP-3 might contribute to basal cell apoptosis in cutaneous lesions, whereas none of the MMPs was overexpressed. In contrast, expression of MMPs-1, and -19 and TIMPs 1 and 3 was observed in intestinal graft-versus-host lesions.

\section{MATERIALS AND METHODS}

\section{Samples}

Formalin-fixed, paraffin-embedded specimens of intestine $(n=13)$ and skin $(n=9)$ from 16 patients were obtained from the Department of Pathology, Helsinki University Central Hospital. Intestinal and skin specimens were from different patients. Fifteen patients had undergone bone marrow transplantation and one patient, liver transplantation. Each sample was investigated by an experienced pathologist, and the diagnosis of cutaneous graftversus-host disease was verified by a dermatopathologist. Cutaneous and intestinal samples were graded (Tables 1 and 2) according to previously published criteria $(24,25)$.

\section{In Situ Hybridization}

The production and specificity of the anti-sense human MMP-1, -3, -7, -10, and -12 and TIMPs-1 and -3 cRNA probes have been described $(10,26-$ 29). After treatment with proteinase $K, 4-\mu \mathrm{m}$ sec-

TABLE 1. Clinicopathological Information and In Situ Hybridization or Immunohistochemistry Results for Patients with Cutaneous GVHD after Bone Marrow Transplantation

\begin{tabular}{|c|c|c|c|c|c|c|c|c|c|c|c|c|c|}
\hline Patient & Sex & Age & Grade & Time from Transplantation & MMP-1 & MMP-3 & TIMP-1 & TIMP-3 & HME & S2 & M & -92 & -19 \\
\hline 1 & $\mathrm{~F}$ & 30 & III & $2 \mathrm{mo} A M L$ & - & - & $\mathrm{s}+\mathrm{e}+$ & $\mathrm{e}++\mathrm{et}+\mathrm{s}+$ & - & - & SG + & - & - \\
\hline 2 & M & 45 & III & 4 mo PBC $^{*}$ & - & - & $\mathrm{s}+++$ & $\mathrm{e}+++\mathrm{et}+\mathrm{s}++$ & - & - & SG + & $(+)$ & et + \\
\hline 3 & $\mathrm{~F}$ & 52 & III & $1 \mathrm{mo} \mathrm{CML}$ & - & - & $\mathrm{s}++$ & $\mathrm{e}+++\mathrm{et}+\mathrm{s}+$ & - & - & SG+ & - & et + \\
\hline 4 & M & 46 & II & $6 \mathrm{mo}$ AML & - & - & - & $\mathrm{e}+++\mathrm{et}+\mathrm{s}(+)$ & - & - & SG + & - & - \\
\hline \multirow[t]{2}{*}{5} & M & 17 & Early st of late & $6 \mathrm{mo}$ ALL & - & - & $\mathrm{e}+$ & $\mathrm{e}+\mathrm{s}-$ & - & - & - & - & - \\
\hline & & & I & 6 mo ALL & - & - & - & $\mathrm{e}+++\mathrm{et}+\mathrm{s}+$ & - & - & SG + & - & et $(+)$ \\
\hline 6 & M & 11 & Late st of late & 19 mo AA & - & - & $\mathrm{s}(+)$ & $\mathrm{e}+++\mathrm{et}+\mathrm{s}++$ & - & - & SG + & - & - \\
\hline 7 & M & 51 & III & 7 mo CLL & - & N.D. & N.D. & N.D. & - & - & N.D. & - & - \\
\hline 8 & $\mathrm{M}$ & 52 & II & 2 mo CLL & - & N.D. & N.D. & N.D. & - & - & N.D. & - & et $(+)$ \\
\hline
\end{tabular}

$\mathrm{e}=$ epithelium; $\mathrm{s}=$ stroma; et $=$ endothelium; $\mathrm{SG}=$ sweat gland; N.D. $=$ not determined; $\mathrm{PBC}=$ primary biliary cirrhosis; $\mathrm{CML}=$ chronic myeloid leukaemia; AA = aplastic anemia; AML = acute myeloid leukaemia; ALL = acute lymphocytic leukemia; CLL = chronic lymphocytic leukemia.

* Liver transplantation.

$+++=$ specific signal in large number of cells; $++=$ specific signal in moderate number of cells; $+=$ specific signal in low number of cells; $(+)=$ specific signal in occasional cells; - = no specific signal detected. 
TABLE 2. Clinocopathological Information and In Situ Hybridization or Immunohistochemistry Results for Patients with Intestinal GVHD after Bone Marrow Transplantation

\begin{tabular}{|c|c|c|c|c|c|c|c|c|c|c|c|c|c|c|}
\hline Patient & Sex & Age & Grade & $\begin{array}{c}\text { Time from } \\
\text { Transplantation }\end{array}$ & CMV & MMP-1 & MMP-3 & TIMP-1 & TIMP-3 & S2 & M & HME & -92 & -19 \\
\hline 1 & $\mathrm{~F}$ & 56 & I & $1 \mathrm{mo} \mathrm{CML}$ & N.D. & $\mathrm{s}-\mathrm{e}-$ & - & + sube & - & - & - & - & - & $\mathrm{se}+$ \\
\hline \multirow[t]{3}{*}{2} & $\mathrm{M}$ & 41 & III & $1 \mathrm{mo} \mathrm{CML}$ & + & e+ & - & ++ sube & ++ & - & $\mathrm{e}(+)$ & - & - & $\operatorname{ce}(+) \operatorname{se}(+)$ \\
\hline & & & III & $5 \mathrm{mo} \mathrm{CML}$ & - & $\mathrm{s}+\mathrm{e}-$ & ++ & $\begin{array}{c}++ \\
\text { sube }\end{array}$ & ++ & - & $\mathrm{e}(+)$ & - & - & - \\
\hline & & & III & 5 mo CML & - & $\begin{array}{c}\mathrm{s}(+) \\
\mathrm{e}-\end{array}$ & - & $\begin{array}{c}++ \\
\text { sube } \\
\text { crypt }\end{array}$ & $(+)$ & - & $\mathrm{e}(+)$ & - & - & - \\
\hline \multirow[t]{3}{*}{3} & $\mathrm{M}$ & 51 & II & 1 mo myel & - & $++\mathrm{e}+$ & $(+)$ & $\begin{array}{l}++ \\
\text { sube }\end{array}$ & $(+)$ & - & - & - & $(+)$ & - \\
\hline & & & III & 1 mo myel & - & - & - & + crypt & + & - & - & - & - & $\operatorname{ce}(+) \mathrm{se}+$ \\
\hline & & & III & 3 mo myel & N.D. & $\mathrm{e}^{+}$ & - & $\begin{array}{l}+++ \\
\text { sube }\end{array}$ & +++ & - & $\mathrm{e}(+)$ & - & $(+)$ & $\operatorname{ce}(+)$ \\
\hline \multirow[t]{2}{*}{4} & $\mathrm{M}$ & 53 & II & $2 \mathrm{mo} \mathrm{CML}$ & - & $\mathrm{e}(+)$ & - & ++ sube & ++ & - & - & - & - & ce + \\
\hline & & & II & $6 \mathrm{mo} \mathrm{CML}$ & N.D. & $\mathrm{e}(+) \mathrm{s}(+)$ & $(+)$ & $\begin{array}{c}++ \text { sube } \\
\text { crypt }\end{array}$ & + & - & $\mathrm{e}(+)$ & - & - & $\mathrm{ce}+\mathrm{se}+$ \\
\hline 5 & $\mathrm{~F}$ & 41 & II & 1 mo myel & + & $+\mathrm{e}+$ & $(+)$ & $\begin{array}{c}\text { + sube } \\
\text { crypt }\end{array}$ & $(+)$ & $(+)$ & - & - & + & ce + \\
\hline 6 & $\mathrm{M}$ & 49 & III & 1 mo myel & - & - & - & + & - & N.D. & N.D. & - & $(+)$ & $\mathrm{ce}++$ \\
\hline 7 & $\mathrm{M}$ & 48 & III & $1 \mathrm{mo}$ CML & + & + & + & - & - & N.D. & N.D. & - & + & $\mathrm{se}+$ \\
\hline 8 & $\mathrm{~F}$ & 46 & III & 2 mo AML & + & $\mathrm{e}++$ & - & $\begin{array}{l}+++ \\
\text { sube }\end{array}$ & ++ & - & - & - & - & s+ \\
\hline
\end{tabular}

sube = subepithelial cells; se = surface epithelium; ce = crypt epithelium; myel = myeloma.

$+++=$ specific signal in large number of cells; $++=$ specific signal in moderate number of cells; $+=$ specific signal in low number of cells; $(+)=$ specific signal in occasional cells; $-=$ no specific signal detected.

tions were hybridized with ${ }^{35} \mathrm{~S}$-labeled cRNA probes overnight in a humidified chamber at $50-55^{\circ} \mathrm{C}$, washed under stringent conditions, and treated with RNAse A to minimize nonspecific signal as described $(11,30)$. Photographic emulsion was developed after 20-45 days of autoradiography, and the slides were stained with hematoxylin and eosin. Samples previously known positive for each probe were used as positive controls: ulcerative colitis for MMPs 1, 3, 7, and 12; wounds for MMP-10 and for TIMPs 1 and 3. Each tissue was stained twice in separate experiments and analyzed by two investigators independently.

To detect fragmented DNA of apoptotic cells in the paraffin sections, a TUNEL (terminal deoxytransferase-mediated digoxin-dUTP nick end labeling) in situ technique (Apoptag; Oncor Inc., Gaithersburg, $\mathrm{MD})$ was used as described elsewhere (31).

\section{Immunohistochemistry}

Immunostainings were performed by the avidinbiotin-peroxidase complex technique (Vectastain ABC kit; Vector Laboratories, Burlingame, CA). Antibodies were incubated on tissue sections overnight at $+4^{\circ}$ C. Diaminobenzidine was used as chromogenic substrate and Harris hematoxylin as counterstain, as described previously in detail (32). For TIMP-3, sections were pretreated by antigen retrieval in $95^{\circ} \mathrm{C}$ for 25 minutes (DAKO, antigen retrieval solution), and for Apoptag and MMP-9, sections were pretreated with $10 \mathrm{mg} / \mathrm{mL}$ trypsin. MMP-19 and TGF- $\beta$ stainings did not require pretreatment. Antibody dilutions were as follows: for
anti-TIMP-3 (IM43T, Oncogene, Boston, MA), 1:1500; for anti-MMP-19 (RDI-MMP19abR, Research Diagnostics Inc., Flanders, NJ), 1:70; for TGF- $\beta$ (MAB1032, Chemicon), 1:500; and for antiMMP-9 (GE213, Diabor, Oulu, Finland), 1:400.

\section{RESULTS}

\section{Skin}

TIMP-3 mRNA was detected in 7/7 samples (Table 1). In situ hybridization signal was strong in lesional keratinocytes (Fig. 1A) and appeared to concentrate in areas with vacuolizing and apoptotic keratinocytes in the basal cell layer (Fig. 1A-B). There was no evidence of vacuolization in the basal cell layer when TIMP-3 was absent (Fig. 1A-B). TIMP-3 protein co-localized with corresponding mRNA (Fig. 1D-E). Because TIMP-3 has recently been implicated in apoptosis $(33,34)$, the Apoptag kit was used to identify apoptotic keratinocytes: large amounts of apoptotic cells were detected in affected epidermis (Fig. 1C). Regions with apoptotic keratinocytes were also positive for TIMP-3 mRNA (Fig. 1A-C). TIMP-3 was expressed also in the dermis by vascular endothelial cells and perivascular mononuclear cells (Fig. 1D). There was a tendency for elevated stromal expression of TIMP-3 with increasing grade (Table 1). Keratinocytes of normal intact epidermis do not express TIMP-3 $(29,35)$.

TGF- $\beta$ is known to induce TIMP-3 expression in primary keratinocytes (29). Furthermore, TGF- $\beta$ antibodies prevented lung and skin fibrosis in a murine model for sclerodermatous graft-versus-host 


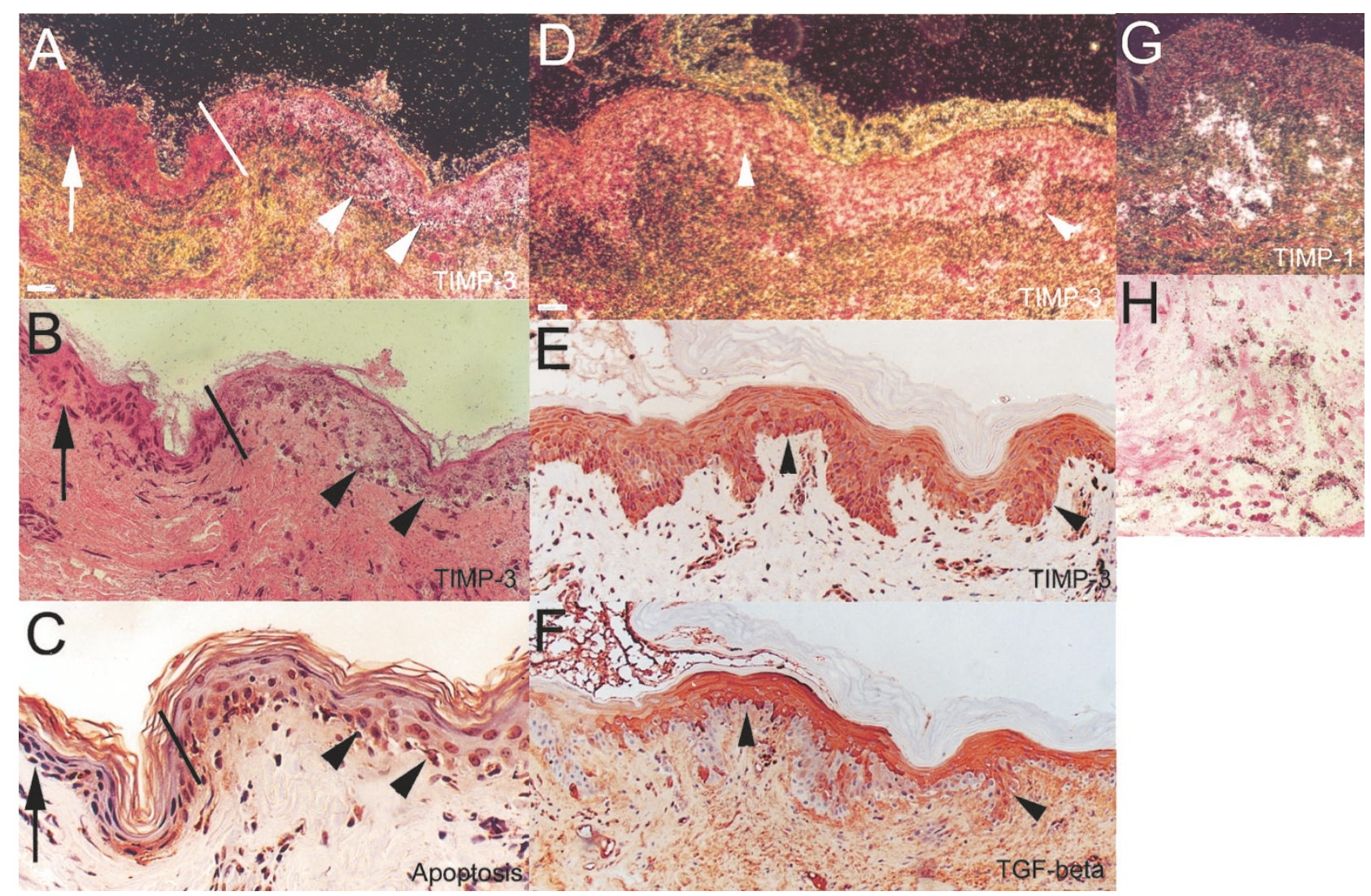

FIGURE 1. Expression of TIMPs 1 and 3 in cutaneous lesions of graft-versus-host disease. A, dark-field image of TIMP-3 mRNA-positive lesional keratinocytes. B, corresponding bright-field image. Arrowheads depict the vacuolizing basal cell layer. Arrow depicts intact epidermis. The line points out the area between affected (on right-hand side) and unaffected epidermis (on left-hand side). C, apoptotic keratinocytes with fragmented DNA identified by TUNEL in situ technique in a serial section. D, dark-field image of TIMP-3 mRNA expression in another sample of cutaneous graft-versus-host disease. E, immunohistochemical staining of a nearby section, showing TIMP-3 protein. F, immunohistochemical staining on a serial section to $\mathbf{E}$ using antibodies against TGF- $\beta 1$ protein. Arrows depict corresponding spots in D-F. G, TIMP-1 mRNA expression in a cutaneous lesion. H, higher magnification of stromal TIMP-1-expressing cells. Scale bars: $50 \mu \mathrm{m}(\mathbf{D}-\mathbf{G}) ; 25 \mu \mathrm{m}(\mathbf{A}-\mathbf{C}, \mathbf{H})$.

disease (36). Thus, we performed TGF- $\beta$ immunostainings on nearby sections for those used for TIMP-3 in situ hybridization experiments. TGF- $\beta-$ expressing keratinocytes were found in TIMP-3 positive areas (Fig. 1D, F).

TIMP-1 mRNA was detected in 5/7 samples. In contrast to TIMP-3, which was abundantly expressed by epidermal keratinocytes, TIMP-1 was expressed mainly by dermal endothelial cells and perivascular mononuclear cells (Fig. 1G-H) beneath epidermis affected by graft-versus-host disease. Epidermal expression was detected in a few cells in $2 / 7$ cases.

Signal for MMPs $-1,-3,-9,-10$, or -12 was not seen in any sample (Table 1). Sweat glands were positive for MMP-7 in most cases (data not shown), which is in accordance with our previous data (37). Positive staining for MMP-19 was found in occasional fibroblasts and endothelial cells in 4/9 samples (Table 1), in accordance with previous studies (38). MMP-19 was not detected in areas of keratinocyte apoptosis or vacuolar degeneration (data not shown).

\section{Intestine}

Expression of MMPs and TIMPs was studied also in gut affected by graft-versus-host disease. The only MMPs detected in most cases were MMPs-1 and -19 (Table 2). Both TIMP-1 and -3 were abundantly expressed by large amounts of stromal cells.

Expression of MMP-1 mRNA was detected in 9/13 samples. Epithelial expression of MMP-1 was detected in $7 / 13$ samples. In addition to epithelial cells, MMP-1-positive cells included stromal plump, activated fibroblast/macrophage-like cells around destructed crypts (data not shown). In some cases, shedding epithelium expressed MMP-1 mRNA (Fig. 2A-B).

The other MMP found in intestinal lesions was MMP-19. Positive signal was found in 10/13 samples. Cells expressing MMP-19 were mainly epithelial cells located in the crypts (Fig. 2C), but also occasional macrophage/activated fibroblast-like cells in the stroma (Fig. 2D). MMP-19 expression did not associate with apoptosis as judged by TUNEL staining (data not shown). In normal intes- 


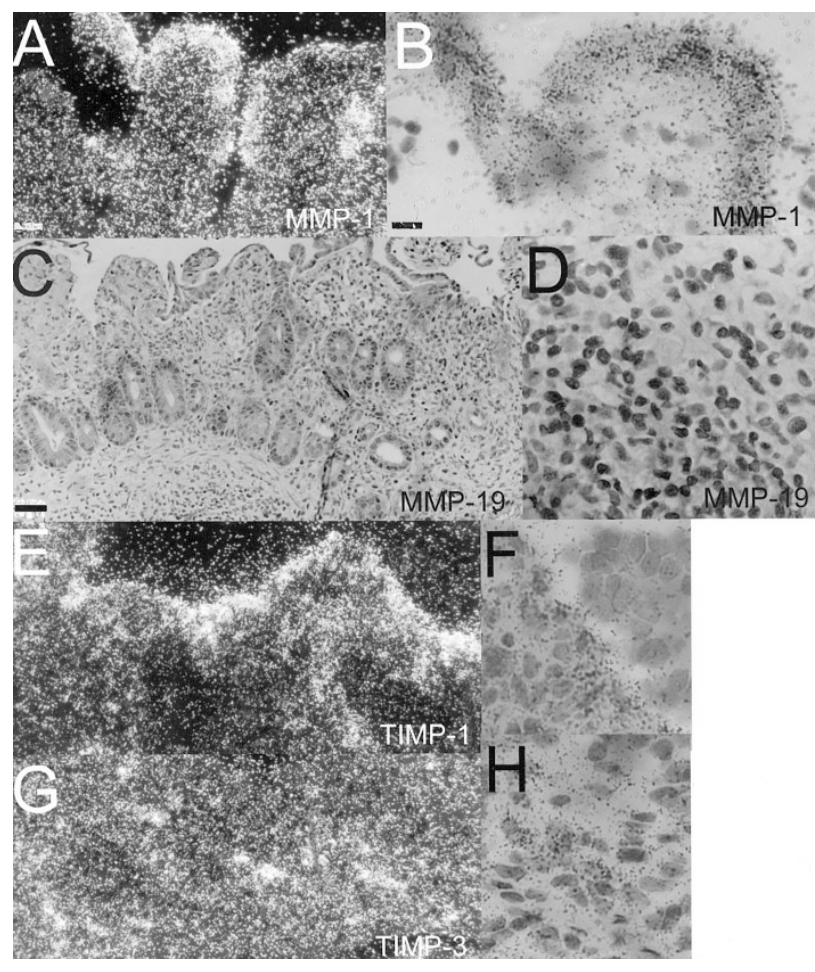

FIGURE 2. Expression of collagenase- 1 and TIMPs 1 and 3 in intestinal lesions of graft-versus-host disease. A, expression of MMP-1 mRNA by shedding epithelial cells in an intestinal lesion. B, higher magnification showing MMP-1-positive cells. C, MMP-19 is expressed in epithelial cells of crypts. D, higher magnification showing stromal macrophage/activated fibroblast-like cells positive for MMP-19. E, TIMP-1 expression in subepithelial cells after the detachment of epithelium. F, higher magnification showing TIMP-1-positive cells. G, TIMP-3 expression by stromal cells in a serial section. $\mathbf{H}$, higher magnification showing TIMP-3-positive cells. Scale bars: $50 \mu \mathrm{m}(\mathbf{C}) ; 25$ $\mu \mathrm{m}(\mathbf{A}, \mathbf{E}, \mathbf{G}) ; 12.5 \mu \mathrm{m}(\mathbf{B}, \mathbf{D}, \mathbf{F}, \mathbf{H})$.

tine, epithelial cells in the crypts were negative for MMP-19 (data not shown).

In contrast to previous data on inflammatory bowel disease $(10,15,16)$, only occasional cells expressed mRNA for MMP-3 in 5/13 samples (Table 2). In one sample, the number of MMP-3-positive cells was comparable to the number of MMP-1expressing cells. MMP-3-positive cells had the appearance of fibroblast/macrophage-like cells and were located around destructed crypts.

MMPs 7 and 10, previously associated with enterocyte migration $(10,15)$, were found in $5 / 13$ and $1 / 13$ samples, respectively (Table 2). Surprisingly, we did not detect MMP-12 mRNA in any biopsy from graftversus-host disease affected intestine. Immunohistochemistry revealed MMP-9 in occasional stromal cells in $5 / 13$ samples (data not shown).

Signal for TIMP-1 and TIMP-3 was detected in $12 / 13$ and $10 / 13$ cases, respectively. TIMP-1 was expressed mainly in superficial regions of injured mucosa (Fig. 2E-F), whereas TIMP-3 expression concentrated in deeper parts of mucosa (Fig. 2G$\mathrm{H})$, particularly in stromal areas with diminished crypt density. TIMP-1 expression concentrated in surface parts of mucosa and was particularly strong in subepithelial cells at sites where epithelium had been shed away. Both TIMP-1 and -3 were expressed by fibroblast/macrophage-like cells, whereas epithelial cells remained negative, which is in accordance with our previous data $(10,15)$. The number of cells expressing TIMP-1 exceeded the number of TIMP-3 expressing cells in all cases.

\section{DISCUSSION}

Experimental studies with mice and rats have demonstrated the crucial role for TNF- $\alpha$ and FasFasL in the pathogenesis of acute graft-versus-host disease (22). Because MMP inhibitor prevented lethal acute graft-versus-host disease in mice $(19,20)$, we hypothesized that in addition to the cytokinemodulating effect of MMPs, they might also be lesionally expressed and contribute to destruction on the tissue level. In this work, we studied the expression of MMPs and TIMPs previously shown to be abundantly expressed in intestinal ulcers related to inflammatory bowel disease. We did not detect marked up-regulation of any MMP studied in stromal cells of lesional gut, but MMP-19 was expressed in the crypt epithelium. In situ hybridization or immunohistochemistry did not reveal MMP-1, $-3,-7,-9,-10$, or -12 expression in skin lesions. However, TIMPs 1 and 3 were up-regulated in both intestinal and skin lesions, suggesting that altered MMP-TIMP balance would favor matrix synthesis rather than breakdown.

In cutaneous lesions, we did not detect mRNA for any MMP studied, but TIMPs- 1 and -3 , particularly TIMP-3 mRNA and protein, were clearly up-regulated (Table 1; Fig. 1). Interestingly, vacuolar degeneration, a typical histopathological finding for graft-versushost disease, was detected in epidermal areas positive for TIMP-3 (Fig. 1), whereas in TIMP-3-negative areas, these findings were absent. TIMP-3 has been implicated in apoptosis $(33,34)$, and our TUNEL staining demonstrated large numbers of apoptotic keratinocytes in areas affected with graft-versus-host disease. Therefore, TIMP-3 might function as a proapoptotic agent in this disease. To our knowledge, there are no data on TIMP-3 in other cutaneous disorders associated with apoptosis, such as lichen planus or erythema multiforme. The finding of TIMP-3 up-regulation in the stroma of high-grade and late graft-versus-host disease is in accordance with our earlier results that TIMP-3 is also overexpressed in other skin disorders associated with severe dermal fibrosis, such as scleroderma (12).

Antibodies for TGF- $\beta$ prevented the development of skin and lung fibrosis in a murine model of sclerodermatous graft-versus-host disease (36). The same cytokine induces expression of TIMP-3 in keratino- 
cytes (29), whereas TNF- $\alpha$ has no effect. As TGF- $\beta$ protein was produced by keratinocytes in TIMP-3 positive areas in cutaneous graft-versus-host disease, TIMP-3 might be up-regulated by TGF- $\beta$.

TIMP-3 was expressed by epidermal keratinocytes, but also by dermal endothelial cells, analogously to our previous data on endothelial TIMP-3 expression in the neoangiogenic vasculature of intestinal ulcers (10). TIMP-1 was expressed only by dermal macrophage/fibroblast-like cells. Lack of MMP expression and up-regulation of dermal MMP inhibitors may lead to the accumulation of extracellular matrix and fibrosis, both important histological findings in chronic cutaneous graft-versus-host disease. In fact, we have previously demonstrated TGF- $\beta$-mediated activation of TIMP-3 in sclerodermatous skin fibroblasts in culture (12).

MMP-1 and MMP-3 are abundantly expressed in inflammatory bowel disease-related intestinal ulcers and duodenal epithelium of patients with celiac disease $(10,15,16,39)$. MMPs have been implicated in the degradation of mucosal extracellular matrix that leads to ulcer formation. In this study, we found only occasional MMP-3-expressing cells, whereas MMP-1 was expressed in the majority of intestinal biopsies. MMP-1 expression was detected in occasional epithelial cells in regions with epithelial injury, but extensive stromal expression, comparable to that in inflammatory bowel disease, was absent. Epithelial MMP-1 expression might be related to epithelial shedding. In an experimental inflammatory bowel disease model, the gut injury has been found to depend on MMP-3 production (17, 40). However, our current results indicate that in graft-versus-host disease, MMPs do not function in tissue destruction, or at least destructive metalloenzymes differ from those considered to be important in inflammatory bowel disease.

Both TIMPs were abundant in intestinal biopsies. TIMP-1 expression concentrated in superficial regions, particularly in areas where epithelium was absent, giving the impression that lack of epithelial cells induces TIMP-1 expression by subepithelial cells. TIMPs inhibit the enzymatic activity of several MMPs and thereby protect extracellular matrix from degradation. Thus, TIMP-1 might stabilize newly synthesized basement membrane and contribute to the wound-healing process by helping to maintain an optimal environment for migrating epithelial cells. TIMP-3 expression was detected in deeper parts of the mucosa, particularly in areas with total crypt destruction, possibly participating in the scarring process. In normal intestine, only occasional cells expressing TIMP-3 have been reported (10).

Because the expression of MMPs-7 and -10 seem to be restricted to wound healing, epithelial cell migration, and malignancies of the gastrointestinal tract $(10,15,41)$, it is not surprising that we did not detect mRNA for these MMPs in gut affected by graft-versus-host disease. MMP-12 is usually produced by macrophages and overexpressed by duodenal subepithelial macrophages in celiac disease as well as in ulcers of patients with inflammatory bowel disease $(9,10,15)$. In this study, we failed to detect mRNA for MMP-12 in any intestinal or cutaneous sample, although our positive controls worked. Obviously, graft-versus-host disease leads to an inflammatory reaction of the gut mucosa, including the activation of macrophages. However, after bone marrow transplantation, the patients are strongly immunosuppressed, leading to a dysfunction of the immunological defense system, including macrophages. This might explain the lack of MMP-12 expression in inflammatory reaction seen in intestinal graft-versus-host disease.

Our results indicate that the MMP expression profile of intestinal graft-versus-host disease differs from that of other T-cell-mediated destructive conditions, namely inflammatory bowel disease and celiac disease. Whereas MMP expression was differentially regulated in lesions of skin and gut graftversus-host disease, TIMPs were up-regulated in both organs. TIMP-3, in particular, may contribute to keratinocyte apoptosis.

Acknowledgments: The authors thank Dr. ArjaLeena Kariniemi for her pathology expertise, Mrs. Alli Tallqvist for her excellent technical assistance, and Drs. Steven Shapiro, Veli-Matti Kähäri, and Lynn Matrisian for plasmids.

\section{REFERENCES}

1. Goker H, Haznedaroglu IC, Chao NJ. Acute graft-vs-host disease: pathobiology and management [review]. Exp Hematol 2001;29:259-77.

2. Ferrara JL, Deeg HJ. Graft-versus-host disease. N Engl J Med 1991;324:667-74.

3. Nagase H, Woessner JF Jr. Matrix metalloproteinases. J Biol Chem 1999;274:21491-4.

4. Lohi J, Wilson CL, Roby JD, Parks WC. Epilysin, a novel human matrix metalloproteinase (MMP-28) expressed in testis and keratinocytes and in response to injury. J Biol Chem 2001;276:10134-44.

5. Westermarck J, Kahari VM. Regulation of matrix metalloproteinase expression in tumor invasion. FASEB J 1999;13:781-92.

6. Hofmann UB, Westphal JR, Van Muijen GN, Ruiter DJ. Matrix metalloproteinases in human melanoma. J Invest Dermatol 2000;115:337-44.

7. Apte SS, Olsen BR, Murphy G. The gene structure of tissue inhibitor of metalloproteinases (TIMP)-3 and its inhibitory activities define the distinct TIMP gene family. J Biol Chem 1995;270:14313-8.

8. Amour A, Knight CG, Webster A, Slocombe PM, Stephens PE, Knauper $\mathrm{V}$, et al. The in vitro activity of ADAM-10 is inhibited by TIMP-1 and TIMP-3. FEBS Lett 2000;473:275-9.

9. Salmela MT, Pender SL, Reunala T, MacDonald T, SaarialhoKere U. Parallel expression of macrophage metalloelastase (MMP-12) in duodenal and skin lesions of patients with dermatitis herpetiformis. Gut 2001;48:496-502. 
10. Vaalamo M, Karjalainen-Lindsberg ML, Puolakkainen P, Kere J, Saarialho-Kere U. Distinct expression profiles of stromelysin-2 (MMP-10), collagenase-3 (MMP-13), macrophage metalloelastase (MMP-12), and tissue inhibitor of metalloproteinases-3 (TIMP-3) in intestinal ulcerations. Am J Pathol 1998;152:1005-14.

11. Saarialho-Kere UK, Chang ES, Welgus HG, Parks WC. Expression of interstitial collagenase, 92-kDa gelatinase, and tissue inhibitor of metalloproteinases- 1 in granuloma annulare and necrobiosis lipoidica diabeticorum. J Invest Dermatol 1993;100:335-42.

12. Mattila L, Airola K, Ahonen M, Hietarinta M, Black C, Saarialho-Kere $\mathrm{U}$, et al. Activation of tissue inhibitor of metalloproteinases-3 (TIMP-3) mRNA expression in scleroderma skin fibroblasts. J Invest Dermatol 1998;110:416-21.

13. Giannelli G, Brassard J, Foti C, Stetler-Stevenson WG, FalkMarzillier J, Zambonin-Zallone A, et al. Altered expression of basement membrane proteins and their integrin receptors in lichen planus: possible pathogenetic role of gelatinases A and B. Lab Invest 1996;74:1091-104.

14. Vaalamo M, Kariniemi AL, Shapiro SD, Saarialho-Kere U. Enhanced expression of human metalloelastase (MMP-12) in cutaneous granulomas and macrophage migration. J Invest Dermatol 1999;112:499-505.

15. Saarialho-Kere UK, Vaalamo M, Puolakkainen P, Airola K, Parks WC, Karjalainen-Lindsberg ML. Enhanced expression of matrilysin, collagenase, and stromelysin-1 in gastrointestinal ulcers. Am J Pathol 1996;148:519-26.

16. Pender SL, Salmela MT, Monteleone G, Schnapp D, McKenzie C, Spencer J, et al. Ligation of alpha4betal integrin on human intestinal mucosal mesenchymal cells selectively Up-regulates membrane type-1 matrix metalloproteinase and confers a migratory phenotype. Am J Pathol 2000;157: 1955-62.

17. Pender SL, Tickle SP, Docherty AJ, Howie D, Wathen NC, MacDonald TT. A major role for matrix metalloproteinases in T cell injury in the gut. J Immunol 1997;158:1582-90.

18. Monteleone G, MacDonald TT, Wathen NC, Pallone F, Pender SL. Enhancing Lamina propria Th1 cell responses with interleukin 12 produces severe tissue injury. Gastroenterology 1999;117:1069-77.

19. Hattori K, Hirano T, Ushiyama C, Miyajima H, Yamakawa N, Ebata T, et al. A metalloproteinase inhibitor prevents lethal acute graft-versus-host disease in mice. Blood 1997;90:542-8.

20. Hattori K, Hirano T, Oshimi K, Yagita H, Okumura K. A metalloproteinase inhibitor prevents acute graft-versus-host disease while preserving the graft-versus-leukaemia effect of allogeneic bone marrow transplantation. Leuk Lymphoma 2000;38:553-61.

21. Powell WC, Fingleton B, Wilson CL, Boothby M, Matrisian LM. The metalloproteinase matrilysin proteolytically generates active soluble Fas ligand and potentiates epithelial cell apoptosis. Curr Biol 1999;9:1441-7.

22. Hattori K, Hirano T, Miyajima H, Yamakawa N, Tateno M, Oshimi K, et al. Differential effects of anti-Fas ligand and anti-tumor necrosis factor alpha antibodies on acute graftversus-host disease pathologies. Blood 1998;91:4051-5.

23. McCawley LJ, Matrisian LM. Matrix metalloproteinases: multifunctional contributors to tumor progression. Mol Med Today 2000;6:149-56.

24. Horn TD. Acute cutaneous eruptions after marrow ablation: roses by other names? J Cutan Pathol 1994;21:385-92.

25. Sviland L. The pathology of bone marrow transplantation. Curr Diagn Pathol 2000;6:242-50.

26. Saarialho-Kere UK, Chang ES, Welgus HG, Parks WC. Distinct localization of collagenase and tissue inhibitor of met- alloproteinases expression in wound healing associated with ulcerative pyogenic granuloma. J Clin Invest 1992;90:1952-7.

27. Saarialho-Kere UK, Pentland AP, Birkedal-Hansen H, Parks WC, Welgus HG. Distinct populations of basal keratinocytes express stromelysin-1 and stromelysin-2 in chronic wounds. J Clin Invest 1994;94:79-88.

28. McDonnell S, Navre M, Coffey RJ Jr, Matrisian LM. Expression and localization of the matrix metalloproteinase pump-1 (MMP-7) in human gastric and colon carcinomas. Mol Carcinog 1991;4:527-33.

29. Airola K, Ahonen M, Johansson N, Heikkila P, Kere J, Kahari $\mathrm{VM}$, et al. Human TIMP-3 is expressed during fetal development, hair growth cycle, and cancer progression. J Histochem Cytochem 1998;46:437-47.

30. Prosser IW, Stenmark KR, Suthar M, Crouch EC, Mecham RP, Parks WC. Regional heterogeneity of elastin and collagen gene expression in intralobar arteries in response to hypoxic pulmonary hypertension as demonstrated by in situ hybridization. Am J Pathol 1989;135:1073-88.

31. Airola K, Johansson N, Kariniemi AL, Kahari VM, SaarialhoKere UK. Human collagenase-3 is expressed in malignant squamous epithelium of the skin. J Invest Dermatol 1997; 109:225-31.

32. Saarialho-Kere UK, Kovacs SO, Pentland AP, Olerud JE, Welgus HG, Parks WC. Cell-matrix interactions modulate interstitial collagenase expression by human keratinocytes actively involved in wound healing. J Clin Invest 1993;92:2858-66.

33. Ahonen M, Baker AH, Kahari VM. Adenovirus-mediated gene delivery of tissue inhibitor of metalloproteinases-3 inhibits invasion and induces apoptosis in melanoma cells. Cancer Res 1998;58:2310-5.

34. Baker AH, Zaltsman AB, George SJ, Newby AC. Divergent effects of tissue inhibitor of metalloproteinase-1, -2 , or -3 overexpression on rat vascular smooth muscle cell invasion, proliferation, and death in vitro. TIMP-3 promotes apoptosis. J Clin Invest 1998;101:1478-87.

35. Vaalamo M, Leivo T, Saarialho-Kere U. Differential expression of tissue inhibitors of metalloproteinases (TIMP-1, -2, -3 , and -4 ) in normal and aberrant wound healing. Hum Pathol 1999;30:795-802.

36. McCormick LL, Zhang Y, Tootell E, Gilliam AC. Anti-TGFbeta treatment prevents skin and lung fibrosis in murine sclerodermatous graft-versus-host disease: a model for human scleroderma. J Immunol 1999;163:5693-9.

37. Saarialho-Kere UK, Crouch EC, Parks WC. Matrix metalloproteinase matrilysin is constitutively expressed in adult human exocrine epithelium. J Invest Dermatol 1995;105:190-6.

38. Kolb C, Mauch S, Krawinkel U, Sedlacek R. Matrix metalloproteinase-19 in capillary endothelial cells: expression in acutely, but not in chronically, inflamed synovium. Exp Cell Res 1999;250:122-30.

39. Daum S, Bauer U, Foss HD, Schuppan D, Stein H, Riecken $\mathrm{EO}$, et al. Increased expression of mRNA for matrix metalloproteinases- 1 and -3 and tissue inhibitor of metalloproteinases-1 in intestinal biopsy specimens from patients with coeliac disease. Gut 1999;44:17-25.

40. Pender SL, Breese EJ, Gunther U, Howie D, Wathen NC, Schuppan D, et al. Suppression of T cell-mediated injury in human gut by interleukin 10: role of matrix metalloproteinases. Gastroenterology 1998;115:573-83.

41. Fingleton BM, Heppner Goss KJ, Crawford HC, Matrisian LM. Matrilysin in early stage intestinal tumorigenesis. APMIS 1999;107:102-11. 